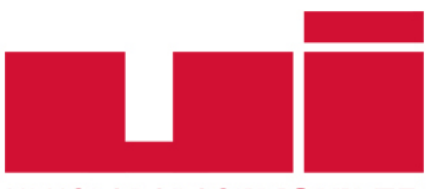

ULLUSLARARASTiLIŞKiLER

Akademik Dergi

Yayın ilkeleri, izinler ve abonelik hakkında ayrıntılı bilgi:

E-mail: bilgi@uidergisi.com.tr

Web: www.uidergisi.com.tr

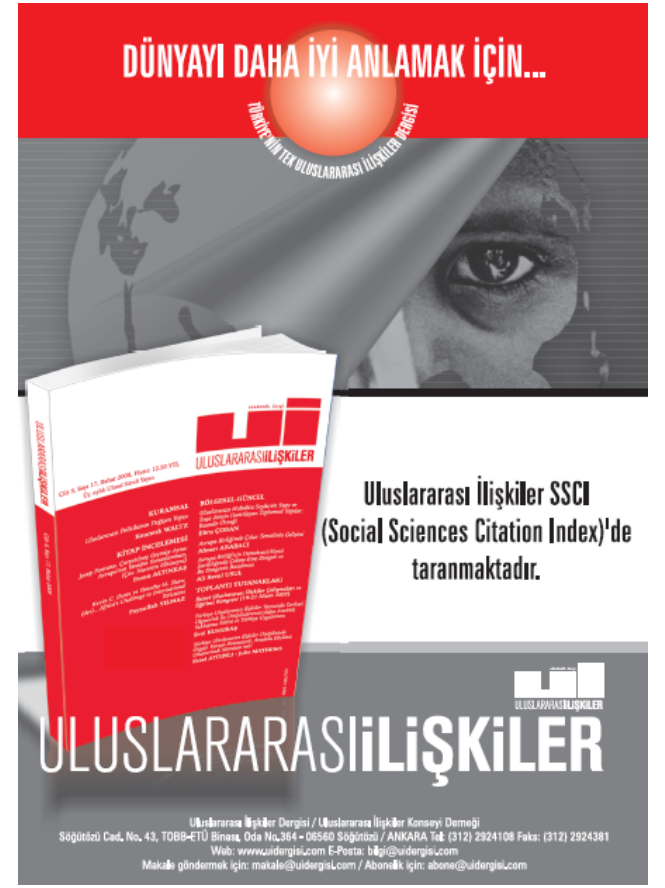

Sosyal İnşacılık Açısından Kosova'nın Kimliği: Bağımsızlık Sonrasında Ortak bir "Kosovalı" Kimliği Oluşturmak Mümkün mü?

\author{
Emel G. OKTAY* ve Jonilda RRAPAJ** \\ * Doç. Dr., Hacettepe Üniversitesi, Uluslararası İlişkiler \\ Bölümü \\ ** Doktora Öğrencisi, Ankara Üniversitesi, Uluslararas1 \\ İlişkiler Bölümü
}

Bu makaleye atıf için: Oktay, Emel G. ve Jonilda, Rrapaj, "Sosyal Inşacılık Açısından Kosova'nın Kimliği: Bă̆ımsızlık Sonrasında Ortak Bir "Kosovalı" Kimliği Oluşturmak Mümkün mü?”, Uluslararası İlişkiler, Cilt 13, Sayı 49, 2016, s. 43-59.

Bu makalenin tüm hakları Uluslararası İlişkiler Konseyi Derneği'ne aittir. Önceden yazılı izin alınmadan hiç bir iletişim, kopyalama ya da yayın sistemi kullanılarak yeniden yayımlanamaz, çoğaltılamaz, dağıtılamaz, satılamaz veya herhangi bir şekilde kamunun ücretli/ücretsiz kullanımına sunulamaz. Akademik ve haber amaçlı kısa alıntılar bu kuralın dışındadır.

Aksi belirtilmediği sürece Uluslararası Illişkiler'de yayınlanan yazılarda belirtilen fikirler yalnızca yazarına/yazarlarına aittir. UİK Derneğini, editörleri ve diğer yazarları bağlamaz. 


\title{
Sosyal İnşacılık Açısından Kosova’nın Kimliği: Bağımsızlık Sonrasında Ortak bir "Kosovalı" Kimliği Oluşturmak Mümkün mü?
}

\author{
Emel G. OKTAY \\ Doç. Dr., Uluslararası İlişkiler Bölümü, İ̈BF, Hacettepe Üniversitesi, Ankara. \\ E-posta:emeloktay@yahoo.com \\ Jonilda RRAPAJ \\ Doktora Öğrencisi, Uluslararası İlişkiler Bölümü, Ankara Üniversitesi Siyasal Bilgiler Fakültesi,Ankara. \\ E-posta: r.jonilda@hotmail.com
}

\begin{abstract}
ÖZET
Bu makalede bağımsızlık sonrasında Kosova'da kimlik siyaseti incelenmektedir. Makalede Kosovalı Arnavutlar ile Sırplar arasındaki düşmanlığın doğal veya başlangıçtan beri gelen değil Arnavut ve Sırp ulusal kimliğinin oluşturulması sırasında ortaya çıkmış olduğunu iddia eden sosyal inşacı yaklaşım uygulanmaktadır. Ulus ve ulusal kimliğin sosyal olarak inşa edilmiş ve hiçbir zaman tamamlanmayacak, ucu açı bir süreç olduğu kabul edildiğinde, bağımsızlık sonrasında Kosova'da, etnik ya da dini aidiyetlere bağlı olmayan ve vatandaşlık esasına dayalı bir "Kosovalı" kimliğinin oluşturulmasının kuramsal olarak mümkün olabileceği iddia edilmektedir. Kosovảnın bağımsızlık süreci ve sonrası incelendiğinde ise bu kimliğin oluşturulmasının büyük ölçüde yeni Kosova devletinin anayasal temellerini oluşturan hukukun üstünlüğü ve insan haklarına saygı gibi ilkelerin etnik köken ve kültür farkı gözetilmeden tüm Kosova halkına yönelik olarak uygulanmasına bağlı olduğu sonucuna ulaşılmıştır.
\end{abstract}

Anahtar Kelimeler: Milliyetçilik, Ulusal kimlik, Sosyal İnşacılık, Kosova, Ahtisaari Planı.

\section{Identity of Kosovo from the Social Constructivist Perspective: Is Construction of a Common "Kosovar" Identity Possible in the Post-Independence Kosovo?}

\begin{abstract}
This article aims to analyze the identity politics in Kosovo after the independence. It employs social constructivist approach to argue that the enmity between Albanians and the Serbs of Kosovo is not natural or primordial but socially constructed as a by-product of Albanian and Serbian national building processes. Considering nation and national identity as socially constructed and therefore a process never completed, the article claims that it is theoretically possible to construct an all embracing "Kosovar" identity in the post-independence Kosovo by emphasizing citizenship rather than ethnic or religious affinities by the new Kosovo state. However, as the independence period and its aftermath was analyzed, it was concluded that the successful formation of a Kosovar identity remains heavily dependent on the degree to which the newly established Kosovo state is able to apply constitutional principles such as supremacy of law and human rights indiscriminately to all its citizens.
\end{abstract}

Keywords: Nationalism, National Identity, Social Constructivism, Kosovo, Ahtisaari Plan. 


\section{Giriş}

Mart 1998'de başlayan savaştan 17 Şubat 2008'de ilan edilen bağımsızlığa kadar Kosova'nın en önemli sorunu güvenlik meseleleri iken, bağımsızlık sonrası dönemde Kosova devletinin hayata geçirilmesi ve Kosova’da yaşayan tüm halkları kapsayacak bir “Kosovalı” kimliğinin oluşturulması öncelikli konuma gelmiştir. Yüzyıllar boyunca aynı toprakları paylaşmalarına rağmen ulusal kimlikleri birbirlerine karşı düşman algısıyla oluşturulmuş Kosovalı Arnavutlar ve Kosovalı Sırpların ortak bir "Kosovalı" kimliği altında birleştirilmesinin oldukça zor olduğu ortadadır. Kosova’nın bağımsızlığının ilanından sonra hem Kosova'da, hem de Balkanlar genelinde istikrar ve güvenliğin sağlanmasının büyük ölçüde çok etnili ve çok kültürlü bir sosyal yapıyı temel alan demokratik bir Kosova devletinin oluşturulmasına bağlı olduğu kabul edilmektedir.

$\mathrm{Bu}$ makalenin temel amacı Kosovalı Arnavutlar ve Kosovalı Sırplar arasındaki sorunlu etkileşimin tarihsel sürecinden yola çıkarak, bağımsızlık sonrası dönemde ortak bir "Kosovalı” kimliğinin oluşturulmasının mümkün olup olamayacağını incelemektir. Araştırmanın kuramsal savı, ulusların varoluşlarından kaynaklanan ve değiştirilmesi mümkün olmayan doğal varlıklar değil, oluşumunda milliyetçiliğin büyük rol oynadığı sosyal olarak inşa edilmiş kurumlar olduğudur. Dolayısı ile "ben” in tanımlanabilmesi için "öteki”nin oluşturulmasından doğan düşmanlıklar sosyal olarak inşa edilmiş ve belli tarihsel ve sosyal şartların içerisine iliştirilmiştir. Arnavutlar ve Sırplar arasında ulusal kimliklerine dayanan ilişkiler de buna bir istisna değildir. Sosyal inşacı yaklaşıma göre ulusal kimliğin, durağan ve değişmez değil, sosyal ve tarihsel süreçler ile şekillendirilmiş, geçişken bir niteliğe sahip olduğu yaklaşımını kabul eden bu çalışmanın temel iddiası başta Arnavutlar ve Sırplar olmak üzere Kosova'da yaşayan tüm etnik grupları kapsayabilecek bir "Kosovalı" kimliğinin oluşturulmasının kuramsal olarak mümkün olabileceğidir. Pratikte ise bu kimliğin oluşturulmasının bağımsız Kosova devletinin anayasal yapısına ve işleyişine bağlı olduğu iddia edilmektedir.

$\mathrm{Bu}$ çerçevede, makalede öncelikle Arnavut ve Sırp milliyetçiliğinin tarihsel gelişimi incelenmekte, Tito döneminde Yugoslavya Sosyalist Federal Cumhuriyeti’nde oluşturulan hassas etnik dengelerin yıkılmasıyla ortaya çıkan kaos ortamı ve savaştan bahsedilmektedir. Mart 1999'da gerçekleşen NATO müdahalesinden Kosova'nın tek taraflı olarak bağımsızlığını ilan ettiği Şubat 2008'e kadar olan dönemde Kosova'da yaşanan siyasi gelişmeler incelendikten sonra, "Kosovalı” kimliğinin oluşum süreci sosyal inşacı kavramsal yaklaşım çerçevesinde analiz edilmektedir. Makalenin son bölümünde ise Kosova kimliğinin oluşturulma sürecinin başarılı olup olmadığı değerlendirilmektedir. Bu çalışma "Kosovalı" kimliğinin oluşturulması bağlamında Kosova'da yaşayan iki temel etnik grubun tarihsel süreç içerisinde birbirleriyle sorunsal etkileşimini milli kimliğin oluşturulması açısından incelemeyi amaçladığından, Arnavutlar ve Sırplar dışında Kosova'da yaşayan diğer etnik grupların en önemlileri olan Türkler, Goraniler, Romanlar ve Boşnaklar bu çalışmanın içerisine dâhil edilmemiştir.

\section{Arnavut ve Sırp Milliyetçiliğinin Tarihsel Gelişimi}

Balkanlarda görülen diğer milliyetçiliklerden farklı olmayan bir şekilde, Arnavutların ve Sırpların ulus inşa etme süreçleri, varlıklarını ve bulundukları topraklar üzerinde birbirlerine karşı hak iddialarını destekleyecek şekilde, efsaneler, hikâyeler, ulusal kahramanlar, semboller ve dini merasimler etrafinda şekillenmiştir. Sırp milliyetçiliğinde, siyasi seçkinler ve Ortodoks Kilisesi, günlük hayatta sürekli olarak efsane ve hikâyeleri canlı tutarak Sırp ulusal kimliğinin oluşturulmasında ve yeniden üretiminde belirleyici unsur olmuştur. Sırbistan'ın en önemli efsanesi, kutsal ülke Kosova'dır. Kosova Sırpların 
“Kudüsü”dür. ${ }^{1}$ Sırpların efsane kralları Stefan Duşan (1331-1355) zamanında Orta Çağ’da kurmuş oldukları Sırbistan Krallığı sırasında inşa edilmiş olan en görkemli anıtlar ve Sırp Ortodoks Kilisesi’nin merkezi Kosova'dadır. 1389 yılında Sırp ordusu ile Osmanlı ordusunun karşı karşıya gelerek savaştıkları ve Sırpların yenilgisiyle sonuçlanan Kosova Savaşı da burada gerçekleşmiştir. ${ }^{2}$ Sırpların 500 sene sürecek Osmanlı egemenliğine girmesine yol açan bu yenilgi Sırp milli bilincinde bir travma etkisi yaratmıştır. Sırplar bu savaşı yenilgi olarak değil, kendi ulusal bilinçlerinin sağlamlaşmasını sağlayan bir zafer olarak değerlendirmektedirler.

Diğer taraftan Arnavutların ulus-inşa etme süreci ve Osmanlı imparatorluğu içerisinde kendilerini, ayrı dil konuşan, kavimsel ve kültürel olarak farklı kimliğe sahip bir millet olarak görmeye başlamaları, ancak kendi varlıklarına karşı bir dış tehdidin ortaya çıkmasıyla mümkün olmuştur. ${ }^{3}$ Osmanlı İmparatorluğunun Balkanlar'da güç kaybetmeye başlamasıyla birlikte, Arnavutların aleyhine Sırp ve Yunan toprak taleplerinin ortaya çıkması, Arnavutlar için alarm zillerinin çalmaya başlamasına sebep olmuştur. Bir Arnavut kimliğinin oluşturulması Arnavutluk'un 1912'deki bağımsızlık ilanı ile birlikte mümkün olmuştur. Fakat, bu sefer de Arnavutların yaşamakta oldukları toprakların bir kısmı, Kosova da dâhil olmak üzere, yeni Arnavutluk devletinin sınırları dışında kalmıştır. Bu tarihten sonra ise Arnavutluk'ta yaşayan Arnavutlar ile Kosova Arnavutları farklı tarihsel süreçlerden geçerek kimlik algılamalarında nispeten farklılaşmışlardır.

Hobsbawm'ın belirttiği gibi “bir ulusu diğerine karşı haklı kılan geçmişidir ve tarihçiler de bu geçmişi üreten kişilerdir”. Ulus kimliklerinin inşa edilmesi sürecinde, hem Sırplar hem de Arnavutlar tarihte istedikleri kısımları hatırlamış, istemediklerini ise unutmayı tercih etmişlerdir. Örneğin, Osmanlı İmparatorluğu dönemi öncesinde ve İmparatorluk süresince iki halkın bir arada yaşamakta olduğu unutulmuştur. Benzer bir şekilde Arnavutların ulusal kahramanı Georg Kastriot İskenderbey’in annesinin Slav kökenli olduğuna da neredeyse hiç değinilmemektedir. ${ }^{5}$ Osmanlı ordusu ile Sırp ordusu, 1389'da Kosova Ovasında karşı karşıya geldiğinde, Arnavutlarla Sırpların Osmanlıya karşı birlikte savaştı̆̆ da unutulmuştur veya unutturulmuştur. ${ }^{6}$

Sırplarla Arnavutlar arasındaki ilişkiler Osmanlı döneminde bozulmaya başlamış ve İmparatorluğun çöküşs süreci içerisinde iki halk arasındaki düşmanlık iyice meydana çıkmıştır. Osmanlı’nın Balkanlar'da hâkimiyeti sağladığı ve güçlü olduğu dönemde Arnavutların büyük kısmı Müslümanlığı benimsemiştir. Benzerşekilde Bosna'da yaşayan Slavhalkın büyükkısmı da Müslümanlığı kabul etmiştir. Osmanlı’nın, dini esas alan, Millet sistemine göre organize ettiği devlet sistemi, Müslümanları gerçek tebaası olarak görmekte ve devlet işlerinde, askerlikte ön planda tutmaktaydı. Ortodoks ve Yahudi milletleri ise vergi vererek kendi adalet ve eğitim sistemlerini korumuşlardır. Osmanlı İmparatorluğu Balkanlar'da gücünü ve otoritesini devam ettirdiği sürece, Arnavut ve Bosnalıların, Ortodoks ve Katolik Hıristiyan komşularının gözünde Türk olarak görülmelerinin bir sakıncası bulunmamaktaydı. Fakat zaman içerisinde Osmanlı İmparatorluğu’nun gücünü kaybetmeye başlaması, milliyetçilik rüzgârlarıyla birlikte Avrupa devletlerinin Osmanlı yönetimindeki gayriMüslimleri bahane ederek Osmanlı Devleti’nin iç işlerine karışmaya başlamalarıyla, Osmanlı

1 Tim Judah, Kosovo: War and Revenge, New Haven, Yale University Press, 2002, s.18.

2 Hugh Poulton, The Balkans: Minorities and States in Conflict, Londra, Minority Rights Publications, 1993, s.57.

3 Piro Misha, "Invention of a Nationalism: Myth and Amnesia", Stephanie Schwandner-Sievers ve Bernd J. Fischer (der.), Albanian Identities: Myth and History, Bloomington, Indiana University Press, 2002, s.34.

4 Eric Hobsbawm ve David J. Kertzer, "Ethnicity and Nationalism in Europe Today", Anthropology Today, Cilt 8, No.1, Şubat 1992, s.3.

5 Oliver Jens Schmit, Skenderbeu, Ardian Klosi (Çev.), Tirane, K \& B, 2009.

6 Noel Malcolm, Kosovo: A Short History, Londra, Macmillan, 1998. 
İmparatorluğu içerisindeki farklı milletler arasındaki ilişkiler bozulmaya başladı. 1877-1878 tarihinde Osmanlı-Rus savaşında Osmanlılarınyenilmesiyle Balkanlar'da yeni bir dönembaşladı. İmparatorluğun Ortodoks tebaası (Bulgarlar, Yunanlılar, Karadağlılar ve Sırplar) ile çoğunluğu Müslüman olan Arnavutlar arasında büyük bir mücadele baş gösterdi. Osmanlı İmparatorluğu'nun, Balkan Savaşları sonrasında Balkanları tamamen terk etmek zorunda kalmasının ardından Arnavut, Boşnak ya da Türk olsun, Müslümanlar için Balkanlarda yaşamak imkânsız hale geldi. Son yüzyıl içerisinde Müslüman halkın büyük bir kısmı ya yok edildi, ya da Türkiye'ye göç etmek zorunda bırakıldı.

Arnavutlar ile Sırplar arasında, ilk kanlı karşılaşma Birinci Balkan Savaşı (Ekim 1912-Mayıs 1913) sırasında gerçekleşti. Sırplar Kosova’yı ele geçirdikten sonra, Türk olarak gördükleri Arnavutlara ve Kosovalı Türklere karşı bir yok etme kampanyasına giriştiler. ${ }^{7}$ Kosova, Birinci Dünya Savaşı́nın sona ermesinden sonra kurulan Sırp, Hırvat ve Sloven Krallığı'nın bir parçası oldu. Kosovalı Arnavutlar da bundan sonra, Cviic'in deyimiyle kendilerini "kültürel, siyasi, ekonomik ve nüfus yapısı olarak yeniden şekillendirmeyi hedefleyen” Belgrad yönetimi altına girdi. ${ }^{8}$

Kosova Arnavutları, İkinci Dünya Savaşı (1939-1945) sırasında Milliyetçiler ve Partizanlar (Komünistler) olarak ikiye bölündü. Milliyetçiler için gerçek düşman Sırplar iken, Partizanların ilk hedefi Sırplarla omuz omuza savaşarak Nazi işgalcileri Kosova'dan çıkarmaktı. Her iki grubun nihai amacı ise savaş bittikten sonra Kosovalı Arnavutlara ait olan toprakların anavatan Arnavutluk'a katılmasıydı. ${ }^{9}$ Malcolm, Partizanların lideri Tito'nun savaş sırasında Bujan'da (Kuzey Arnavutluk) yaptığı toplantılarda, "Kosova Metohija Arnavut nüfusun yoğunlukla yaşadığı bir yerdir ve Kosovalılar geçmişte olduğu gibi şimdi de, Arnavutluk ile birleşmek istemektedirler." dediğini aktarmaktadır. ${ }^{10}$ Savaş sona erdikten sonra ise verilen sözler tutulmamıştır. Arnavut Partizanların da desteğiyle en son Nazi güçleri de Yugoslav topraklarını terk ettikten sonra Kosova, 1945'de Josip Broz Tito liderliğinde kurulan İkinci Yugoslavya’nın bir parçası olmuştur.

\section{Tito Yugoslavya'sı ve Kosova'nın Durumu}

İkinci Dünya Savaşından sonra kurulan İkinci Yugoslavya'da (Tito Yugoslavya’sı) Arnavutlar hem iyi hem kötü dönemlerden geçmişlerdir. Başlangıçta, Arnavutlar, Yugoslavya Federasyonu içerisinde ayrı bir ulusal grup olarak kabul edilmiş ve Arnavutça, Yugoslavya'nın resmi dilleri arasında yer almıştır. ${ }^{11}$ Tito ile Stalin arasındaki çekişmeden dolayı, Yugoslavya’nın Sovyetler Birliği ile yollarını ayırmasından sonra ise Kosovalı Arnavutlar için kâbus dolu günler başlamıştır. Yine İkinci Dünya Savaşı́ndan sonra komünist olan Arnavutluk'un lideri Enver Hoca, hâlâ Stalinci çizgiyi koruduğu ve Sovyetler Birliği’nin etkisi altında olduğu için, Tito Kosova Arnavutlarına, Yugoslavya içerisinde Sovyetler Birliği için çalışan ajanlar muamelesi yapmıştır. Zaten son derece fakir olan Kosova, Yugoslavya'nın komünist blok lideri Sovyetler Birliği ile siyasi ve ekonomik tüm bağlantılarını kesip, içe kapanmasından en çok zarar gören bölge olmuştur. Buna ek olarak, 1966’ya kadar Yugoslavya Devlet Başkan yardımcısı ve istihbarat kurumunun şefi olan Sırp asıllı Rankoviç, Kosova’yı bir polis devleti gibi yönetmeye başlamış ve güvenlik de içerisinde olmak üzere tüm resmi görevlere, Sırpları ve Karadağlıları getirmiştir.

7 Alexander J. Bellamy, “The Human Wrongs in Kosovo”, Ken Booth (der.), Kosovo Tragedy, The Human Rights Dimension, Londra, Frank Cass, 2002, s.106. Malcolm bu dönemde öldürülen Kosovalı Arnavutların sayısını 25 bin olarak vermektedir. Malcolm, Kosovo, s.253.

8 Christopher Cviic, Remaking the Balkans, London, The Royal Institute of International Affairs, 1991, s.18.

9 Poulton, The Balkans, s.59.

10 Malcolm, Kosovo, s.72.

11 Malcolm, Kosovo, s.315-320. 
Avrupa'da en yüksek doğum oranına sahip olan Müslüman Arnavutların Kosova'dan Türkiye’ye göçü çeşitli vesilelerle teşvik edilmiş, 1950-1966 yılları arasında Türk olduğunu beyan eden 400,000'den fazla Kosovalı Arnavut Türkiye'ye göç ettirilmiştir. ${ }^{12}$

Rankoviç'in 1966 'da görevden uzaklaştırılmasının ardından, Kosova Arnavutları için Yugoslavya içerisinde "altın dönem" başlamıştır. ${ }^{13} 1974$ yılında yapılan anayasal değişiklikler sonucunda Yugoslavya Sosyalist Federal Cumhuriyeti'nin (YSFC) altı kurucu cumhuriyetinden birisi olan Surbistan'ın içerisinde yer alan Kosova ve Voyvodina’ya “özerk bölge” statüsü verilmiştir. Kosovo ve Vojvodina’ya kendi eğitim ve yargı sistemi ile polis ve savunma güçleri oluşturmalarının yanı sıra, Yugoslavya’nın kolektif başkanlığında diğer altı cumhuriyetle birlikte bağımsız oy hakkı tanıyan bu yeni düzenleme ile bu özerk bölgeler bir anlamda Sırbistan içerisinde "özerk cumhuriyetler" haline gelmişlerdir. Bununla birlikte, Kosova ve Voyvodina'nın nihai egemenlik hakkı Sırbistan'da kalmaktayd.$^{14}$ O dönemde Tito, YSFC içerisinde, kendisi de dâhil olmak üzere, hiçbir kişi ya da milliyetin diğerlerinin üzerinde egemenlik kuramayacağı, tam bir denge ve fren mekanizması oluşturmaya çalışmıştır.

Yeni anayasaya göre Kosovalı Arnavutlar kendi ulusal bayraklarını ve sembollerini kullanabilme, Arnavutça eğitim ve Arnavutluk ile doğrudan bağlantı kurma imkânlarına sahip olmuşlardı. Buna karşllık Sırplar ise, Kosova ve Voyvodina'nın özerk cumhuriyetler haline getirilerek Sırbistan'dan koparılmasını, yarı Hırvat, yarı Sloven kökenli olan Tito'nun Sırbistan’a ihaneti olarak algıladılar. ${ }^{15}$ Fakat o dönemde, nihai karar verici olan Tito'ya karşı çıkma imkânları yoktu. ${ }^{16} 1974$ 'te kurulan anayasal sistem, Tito'nun 1980 'de ölümü sonucunda, dengeyi sağlayan merkezi otoritenin ortadan kalkması nedeniyle krizden krize sürüklenmeye başladı. Siyasi krize ekonomik sorunların da eklenmesiyle, Yugoslavya'nın tamamında iç gerginlikler daha da arttı. Kosovalı Arnavutlar Sırbistan tarafından kendilerine yöneltilen yeni bir baskı politikasıyla karşı karşıya kaldılar ve içerisinde bulundukları ekonomik ve sosyal sıkıntıları aşmak için tam Cumhuriyet statüsü talebinde bulundular. ${ }^{17}$ Guzina’nın da belirttiği gibi, 1981 yılında Kosova Arnavutlarının başlattığı protesto gösterilerine karşı Sırbistan güçlerinin çok sert tepki vermesi sonucunda Kosovalı Arnavutlar daha da radikalleşmişler, bu da Sırp milliyetçi hareketinin daha da yükselmesine sebep olmuştur. ${ }^{18}$

\section{Sırp ve Arnavut Milliyetçiliğinin Yükselişi ve Kosova'da Savaş}

Ocak 1986'da Sirbistan Bilimler Akademisi bir muhtıra yayınlayarak “Tito Yugoslavya'sının kuruluşundan beri Sırp karşıtı olduğunu ve Arnavutların Kosova’da Sırplara karşı fiziksel, siyasi, hukuksal ve kültürel olarak bir soykırıma giriştiklerini” belirtti. ${ }^{19}$ Poulton’a göre bu muhtıra daha sonra "Slobodan Miloseviç’in başarıyla yönlendireceği Sırp milliyetçiliğinin gerçek başlangıcını" oluşturmaktayd. ${ }^{20}$

12 Zamir Shtylla, “The Deportation of Albanians in Yugoslavia After the Second World War”, K. Prifti et.al. (der.) The Truth on Kosova, Tirana, Encylopedia Publishing House, 1993, s.239.

13 Judah, Kosovo, s.55.

14 James Gow, “Deconstructing Yugoslavia”, Survival, Cilt 33, No.4, 1991, s.294.

15 Malcolm, Kosovo, s.329.

16 Judah, Kosovo, s.57.

17 Branka Magaš, The Destruction of Yugoslavia: Tracking the Break-up, 1980-1992, Londra, Verso, 1993, s.74.

18 Dejan Guzina, "Kosovo or Kosova-Could It Be Both? The Case of Interlocking Serbian and Albanian Nationalisms", Florian Bieber ve Zhidas Daskalovski (der.), Understanding the War in Kosovo, Londra, Frank Cass, 2005, s.33.

19 Laura Silber ve Alan Little, The Death of Yugoslavia, Harmondsworth, Penguin, 1996, s.31-36.

20 Poulton, The Balkans, s.17. 
Siyasi hayatına inanmış bir komünist olarak başlayan Miloseviç, Tito'nun ölümünden sonra Yugoslavya’nın içerisinde düştüğu siyasi belirsizlik ortamında, Sırp halkının Kosova konusundaki hassasiyetlerini son derece iyi kullanarak tüm siyasi rakiplerini geride bırakmayı başardı ve Sırpların ulusal lideri oldu. Sırp medyasının da desteğiyle "Kosova’nın yeniden Sırplaştırılması” sloganıyla saldırgan bir politika izlemeye başladı. Sonuçta, 1989'da Sırbistan Anayasasında yapılan düzenlemelerle Kosova’nın özerkliği kaldırıldı. Kosovalı Arnavutlar, Güney Afrika'daki Apartheid rejimine benzer şekilde tüm siyasi, sosyal, ekonomik ve kültürel haklarından yoksun bırakıldı. ${ }^{21}$ Kosovalı Arnavutların geniş katılımlı protestoları polis gücüyle bastırıldı ve Kosova'da olağanüstü durum ilan edildi. Kosova’nın özerkliğinin kaldırılmasından üç ay sonra, 28 Ocak 1989'da Osmanlı ordusu ile Sırp ordusunun karşılaştı̆̆ Kosova Ovası́nda Sırp Ortodoks Kilisesi’nin de katılımıyla büyük bir tören düzenlendi ve Kosova Meydan Savaşı’nın altı yüzüncü yılı etkileyici bir şekilde anıldı. Miloseviç, tören sırasında heyecanlı kalabalıklara “Kosova’nın nihayet anavatan Sırbistan’a döndüğünü” müjdeledi. ${ }^{22}$

Miloseviç’in saldırgan ve ayırımcı politikalarının devam etmesi üzerine Arnavutlar kendi paralel devlet yapılarını oluşturarak mücadeleye giriştiler. Kosova Demokratik Ligi üyesi İbrahim Rugova, Mayıs 1992'de tek taraflı olarak bağımsızlığını ilan eden Kosova’nın ilk devlet başkanı olarak seçildi. Rugova başından itibaren, Kosovalı Arnavutların da geniş desteğiyle "şiddetten uzak ve pasif direnişi temel alan” bir yönetim felsefesi benimsedi. Rugova aynı zamanda, uluslararası alanda Kosovalı Arnavutların sesinin duyulmasını sağlamaya çalıştı, fakat o sırada Bosna'yı da kan gölüne çevirmekte olan Miloseviç'i durdurma konusunda uluslararası alanda destek bulamadı. Bosna'daki savaş sırasında Sırplara karşı Kosova'da ikinci bir cephe açma yönündeki Hırvatların teklifini de kabul etmedi. ${ }^{23}$ Malcolm'un da belirttiği gibi "Arnavutların mücadeleci karakteri ve silahlı isyanlarla dolu tarihleri" düşünüldüğünde, Rugova’nın bu barışçıl politikasının önemi daha da iyi anlaşılabilir. ${ }^{24}$ Bununla birlikte, $A B D$ ve $A B$ ülkeleri bu barış yanlısı siyasetçinin destek çağrılarını göz ardı etmişlerdir. Hem Bosna'da, hem de Kosova'da saldırgan tarafın açıkça Miloseviç liderliğindeki Sırp ordusu ve milisleri olduğunu bilmelerine rağmen, savaşın sonra ermesinin ancak Miloseviç'in istediklerini elde etmesine bağlı olduğunu kabul ederek yüz binlerce masum insanın öldürülmesine göz yummuşlardır. Nihayet Aralık 1995'de Bosna Savaşı'nı sona erdirecek olan Dayton Anlaşması'nı imzalamak üzere masaya Bosna-Hersek Cumhurbaşkanı ve Bosnalı Müslümanların lideri Alija İzetbegoviç, Bosnalı Hırvatlar adına Hırvatistan Cumhurbaşkanı Franjo Tudjman ile Sırbistan Devlet Başkanı Slobodan Miloseviç’i oturtmakta bir sakınca görmemişlerdir. ${ }^{25}$

Aralık 1995'te imzalanan Dayton Anlaşması görüşmeleri öncesinde ve görüşmeler devam ederken, etnik temizlik sırasının Bosnalı Müslümanlardan sonra Kosova'daki Arnavutlara geleceği konusunda pek çok uyarı olmasına rağmen, Batılı ülkelerin Kosova sorunu hiç yokmuş gibi davranmaları, Rugova'nın barışçıl politikasının da sonunu getirmiştir. Sorunun ancak Miloseviç’in güçlerine karşı silahlı mücadele ile çözülebileceğini iddia eden Kosovalı Arnavut gruplar Kosova Kurtuluş Ordusu (Kosovo Liberation Army-KLA)'nu kurmuşlar ve 1997 başlarında Kosova'daki Sırp yönetiminin unsurlarına karşı silahlı mücadeleye girişmişlerdir. ${ }^{26}$

21 Bellamy, "The Human Wrongs in Kosovo", s.105.

22 Noel Malcolm, Bosnia: A Short History, Londra, Papermac, 1996, s.213.

23 Judah, Kosovo, s.70.

24 Malcolm, Kosovo, s.348.

25 Yugoslavya’nın parçalanması ve Bosna Savaşı süresince önde gelen AB ülkelerinin politikaları konusunda detaylı bir çalışma için bkz. Emel G. Osmançavuşoğlu, The Wars of Yugoslav Dissolution and Britain's Role in Shaping Western Policy: 1991-1995, Ankara, Dışişleri Bakanlığı Stratejik Araştırmalar Merkezi Yayınları, 2000.

26 Zhidas Daskalovski, “Claims to Kosovo: Nationalism and Self-Determination”, Florian Bieber ve Zhidas Daskalovski 


\section{NATO Müdahalesi ve Kosova'nın Bağımsızlığının İlanı}

Miloseviç'in, Kosova Kurtuluş Ordusu'nun silahlı mücadelesine karşı orantısız güç kullanarak, Kosovalı Arnavut sivillere yönelik katliamlarla karşılık vermesi, 1999'da Sırbistan’a karşı uluslararası askeri müdahaleyi getirmiştir. Yaklaşık iki bin kişi öldükten sonra, binlerce Kosovalı Arnavut'un başta Makedonya olmak üzere çoluk çocuk perişan bir şekilde komşu ülkelere akın etmeye başlamasıyla, bölge istikrarının bozularak yeni bir Balkan savaşının ufukta belirmesi, ABD ve AB'yi harekete geçmeye mecbur bırakmıştır. Kosova'da Arnavutlara karşı işlenen savaş suçları dünya kamuoyuna Bosna’da sivillere yönelik olarak yıllarca süren vahşetin tekrar yaşanmakta olduğunu göstermiştir. Bütün bunlara rağmen Miloseviç, Kosova’da Arnavutlara karşı yürüttüğü etnik temizlik politikasından vazgeçmesi için uzun bir süre diplomatik yollarla ikna edilmeye çalışılmış fakat Bosna konusunda olduğu gibi, $A B D$ ve $A B$ 'nin kendi kamuoylarını oyalama taktiği içerisinde olduğunu düşünerek, Kosova'da ateşkesi kabul etmemiştir. Bosna Savaşı sırasındaki yanlış politikaları yüzünden, Soğuk Savaş sonrası dünyada liderlik iddiasının zayıfladığını ve Batı savunma sisteminin en önemli örgütü olan NATO'nun büyük itibar kaybına uğradığını gören ABD, NATO'yu harekete geçirerek, Belgrad dâhil olmak üzere 24 Mart'tan başlayarak Sırbistan' in 78 gün boyunca havadan bombalanmasını sağlamıştır. Batılı ülkelerin niyetinin ciddi olduğunu gören Miloseviç kendisine bağlı güçleri Kosova'dan geri çekmek zorunda kalmıştır. Kosova, Birleşmiş Milletler (BM) Güvenlik Konseyi’nin 1244 sayılı kararıyla Kosova Geçici Yönetim Misyonunun (United Nations Interim Administration Mission in Kosovo, KGYM) kontrolü altına alınmıştır. ${ }^{27}$

KGYM'nin amacı, Kosova'da çalışan demokratik kurumlar oluşturmak, Kosova'nın ekonomik olarak yeniden yapılandırılmasını sağlamak, sivil toplumun geliştirilmesi, hukukun üstünlügünün tesisi, Kosova geleninde ulaşım ve iletişim serbestliğinin sağlanması ve kendi kendisini yönetebilecek hükümet kurumlarının oluşturulması olarak özetlenebilir. ${ }^{28}$ Kosova’nın nihai statüsünün belirlenmesi konusu ise bu koşulların sağlanması şartıyla en sona bırakılmıştır. ${ }^{29}$ Kosovalı Sırplar ise KGYM yönetimini kabul etmeyerek, Surbistan'dan siyasi ve ekonomik destek almaya devam etmişlerdir. ${ }^{30}$

Mart 2004'te Kosovalı Sırplara yönelik saldırılarda can kaybının olması, KGYM'nin Kosovalı Sırplar ile Kosovalı Arnavutlar arasındaki etnik düşmanlığı azaltmak konusunda elde ettiğini sandığı başarının aslında ne kadar yüzeysel olduğunun görülmesine sebep olmuştur. BM Genel Sekreteri’nin Özel Temsilcisi olarak Kosova'daki durum hakkında kapsamlı bir değerlendirme yapmakla görevlendirilen Norveç’in NATO Daimi Temsilcisi Kai Eide, Genel Sekretere sunduğu raporda "Kosova'da çok etnili bir toplumun temelinin atılması konusunda çok az yol alınabildiğini ve acilen Kosova'daki statükonun değiştirilmesinin zorunlu olduğunu” belirtmiştir. ${ }^{31}$

Kosova ile ilgili siyasi süreçte Eide'nini tavsiye ettiği bir sonraki adımın atılmasını destekleyen BM Genel Sekreteri Kofi Annan, Arnavutlar ile Sırplar arasında Kosova'nın nihai statüsü hakkında

(der.), Understanding the War in Kosovo, London, Frank Cass, 2005, s.19.

27 Julie Kim ve Steven Woehrel, "Kosovo and U.S. Policy: Background to Independence”, CRS Report for Congress, 20 Haziran 2008, s. 2.

28 William J. Durch, "Keeping the Peace: Politics and Lessons of the 1990s", William J. Durch (der.), UN Peacekeeping, American Policy and the Uncivil Wars of 1990s, New York, St. Martin's Press, 1996, s.19.

29 Besnik Pula, “The UN in Kosova: Administering Democratization?", Florian Bieber ve Zhidas Daskalovski (der.), Understanding the War in Kosovo, Londra, Frank Cass, 2005, s.195.

30 Bryan Hopkinson, “The International Administration of Kosovo since 1999”, Brad K. Blitz (der.), War and Change in the Balkans: Nationalism, Conflict and Cooperation, Cambridge, Cambridge University Press, 2006, s.171.

31 Kofi Annan, "Letter dated 7 October 2005 from the Secretary-General addressed to the President of the Security Council”, 7 Ekim 2005, http://www.unosek.org, (Erişim Tarihi: 30 Haziran 2015), s.1. 
görüşmelere zemin oluşturacak bir plan hazırlamak üzere Finlandiya eski Devlet Başkanı Martti Ahtisaari'yi görevlendirmiştir. ${ }^{32}$ Ahtisaari’nin bu yöndeki çalışmalarının çerçevesini oluşturmak amacıyla, ABD, İngiltere, Fransa, Almanya, İtalya ve Rusya'dan oluşan Temas Grubu yaptıkları görüşmelerin ardından "Kosova'nın Statüsünün Düzenlenmesi amacıyla Yol Gösterici Prensipler" başlığı altında bir beyanat yayınladı. ${ }^{33}$ Rehber niteliği taşıyan bu belgeye göre alınan tüm önlemler Kosova’nın çok etnili yapısının devamını sağlayacak, Kosova'daki kültürel ve dini mirasın korunmasını mümkün kılacak, Kosova'nın uluslararası örgütler ve finansal kuruluşlar ile etkili bir şekilde işbirliği yapmasını sağlayacak nitelikte olmalıydı. Buna ilaveten Temas Grubu, Kosova’nın 1999 öncesi durumuna asla dönmemesi, toprak bütünlügünün bozulmaması ve parçalanmaması, tamamının veya bir bölümünün herhangi bir ülkenin tamamıyla veya bir bölümüyle birleşmemesi hususlarını da olmazsa olmaz şartlar olarak belirleyen bir bildirge daha hazırladı. ${ }^{34}$ Temas Grubuna göre çözüm, hem azınlıkta olan Kosovalı Sırpların haklarını korumalı, hem de nüfusun çoğunluğunu oluşturan Kosovalı Arnavutlar tarafindan kabul edilebilir nitelikte olmalıydı. ${ }^{35}$

Ahtisaari'nin tüm çabalarına rağmen taraflar arasında uzlaşma konusunda bir ilerleme sağlanamamıştır. Sırplar, Kosova’nın Sırbistan içerisinde özerk bir bölge olmasını isterken, Kosovalı Arnavutlar bağımsızlık için diretiyorlardı. Ahtisaari, "Kosova’nın Statüsünün Düzenlenmesi için Kapsamlı Öneri” başlıklı sonuç raporunda Kosova'ya "denetimli bağımsızlık” verilmesinin tek çözüm olduğunu belirtti. ${ }^{36}$ Öneri ayrıca, anayasa, güvenlik ve ekonomi konuları başta olmak üzere insan haklarının ve toplumsal hakların korunması, dini ve kültürel mirasın koruma altına alınması gibi konuları da içermekteydi. Fakat her şeyden önce Ahtisaari'nin raporu Kosova'nın geleceğini "vatandaşlarının eşitliği üzerine kurulmuş çok etnili, hukukun üstünlügü ilkesine dayanan, insan hakları ve temel özgürlüklerin uluslararası alanda kabul edilmiş en üst düzeyde temsil edildiği, toprakları üzerinde yaşayan tüm insanların barış ve refahını sağlamakla yükümlü demokratik bir yapı" olarak göstermekteydi. ${ }^{37}$

Avrupa Birliği’nin de destek verdiği Ahtisaari’nin teklifi Rusya’nın karşı çıkması yüzünden kabul görmeyince, çoğunluğunu Kosova Arnavutlarının oluşturduğu Kosova Parlamentosu, 17 Şubat 2008'de tek taraflı olarak Kosova’nın bağımsızlığını ilan etti. Bağımsızlık kararı ABD ve AB ülkelerinin çoğu tarafından olumlu karşılandı. ${ }^{38}$ Kosova Başbakanı Haşim Taçi, $A B D$ ve $A B$ ülkelerinin çoğunun bağımsızlık ilanına ancak "Ahtisaari Planında ortaya konan şartların karşılanması konusunda Kosova hükümetinin söz vermesi karşılığında destek verdiklerini” belirtmiştir. ${ }^{39}$ Dolayısı ile Kosova’nın bağımsızlığı ancak hukukun üstünlüğüne dayanan ve çok etnili, çok kültürlü yapıyı destekleyen bir yönetim tarzı benimsenmesi şartıyla kabul edilmiştir.

32 Henry H. Perritt, Kosovo: The Road to Independence, Cambridge, Cambridge University Press, 2010, s.111.

33 Guiding Principles of the Contact Group for a Settlement of the Status of Kosovo, http://www.unosek.org, (Erişim Tarihi: 30 Haziran 2015).

34 Statement by the Contact Group on the Future of Kosovo, 31 Ocak 2006, http://www.unosek.org, (Erişim Tarihi: 30 Haziran 2015).

35 Perritt, Kosovo, s.119-120.

36 Martti Ahtisaari, Report of the Special Envoy of the Secretary-General on Kosovo's Future Status, 15 Mart 2007, http://www. unosek.org, (Erişim Tarihi: 1 Temmuz 2015).

37 Ahrisaari, Report.

38 Cornelius Friesendorf, “Kosovo’s Controversial Independence”, CSS Analysis in Security Policy, Cilt 3, No.29, Mart 2008, http://www.css.ethz.ch/publications/pdfs/CSS-Analyses-29.pdf, (Erişim Tarihi: 1 Temmuz 2015), s.1.

39 Hashim Thaci, Declaration of Independence Speech, 17 Şubat 2008, www.assemblykosova.org, (Erişim Tarihi: 25 Haziran 2015). 


\section{Bağımsızlık Sonrası Kosova'da “Kosovalı Kimliği”’nin Oluşturulması}

Kosova'nın bağımsız bir devlet olarak ortaya çıkmasında, başta ABD liderliğinde Sırbistan'a karşı gerçekleştirilen askeri müdahale olmak üzere, uluslararası faktörlerin etkisi çok büyüktür. Askeri müdahaleden sonra ateşkesin sağlanmasıyla Birleşmiş Milletler gözetiminde ortaya konan Ahtisaari Planı ve bağımsızlık sürecinin bu plana göre yürütülmesi, Kosova devletinin kuruluşunun "yukarıdanaşağıya” doğru yönlendirilen bir proje olduğunu göstermektedir. $A B D$ ve $A B$ başta olmak üzere uluslararası toplumun temel amacı Kosova'da çok etnili ve çok kültürlü, vatandaşlık temelli bir devletin kurulmasıydı. Özellikle AB için, Kosova meselesi sadece insan hakları ihlallerinin sona erdirilerek bu ülkenin bağımsız olması değil, hukukun üstünlüğ̈ prensibiyle işleyen demokratik bir yapı ile tüm Balkanların istikrarına katkıda bulunacak bir siyasi projenin gerçekleştirilmesiydi. $\mathrm{Bu}$ da ancak Kosova'da yaşayan farklı etnik yapıya ve kültüre sahip halklar arasında ortak bir "Kosovalı" kimliğinin oluşturulması ile mümkün olabilirdi. $A B$, Kosova projesi ile toplumları kendi değerleri doğrultusunda dönüştürme konusunda etkili bir güç olduğunu göstermek istiyordu. Dolayısı ile Kosova kimliğinin oluşturulmasının başarısız olması bir anlamda AB'nin kendi yakın çevresinde bile demokrasiyi yerleştirme ve koruma konusunda başarısız bir aktör olduğunun görülmesi anlamına gelecekti.

Massimo d’Azegliónun 19.yy'da İtalyan şehir devletleri arasında siyasi birliğin sağlanmasından sonra söylediği sözler yüz elli yıl sonra Kosova için de geçerlidir: “İtalya’yı oluşturduk, şimdi de İtalyanları oluşturmalıyız" ${ }^{00}$ Benzer şekilde $A B D$ ve $A B$, önce Kosova devletinin oluşturulmasını, ardından da Kosova devletinin "Kosova ulusal kimliğini” oluşturmasını öngören bir proje ile yola çıkmışlardır. ${ }^{41}$

Bağımsızlık sonrasında "Kosovalı” kimliğinin oluşturulmasının kuramsal olarak mümkün olup olmadığı sorusuna bakıldığında ise son otuz yılda milliyetçilik alanında çok önemli çalışmaları bulunan Gellner, Anderson, Hobsbawm ve Breuilly başta olmak üzere modernist düşünürlerin çalışmalarını ele almak gerekmektedir. ${ }^{42} \mathrm{Bu}$ çalışmaların da ortaya koyduğu üzere; milletler gibi, milli kimlikler de, çoğu kez kabul edildiği gibi varoluştan itibaren gelmiş ya da verilmiş değil, zaman içerisinde ekonomik, siyasi ya da toplumsal çeşitli faktörlerin etkisiyle sosyal olarak inşa edilmişlerdir. Dolayısıyla, Verdery'in de belirttiği gibi "millet kavramını, sosyal etkilerin değişen dengeleri ile birlikte farklılaşan ve hiçbir zaman anlamı sabit olmayan bir oluşum olarak görmemiz” gerekir. ${ }^{43}$ Millet kavramıyla yakından bağlantılı olarak kimlik de zaman içerisinde değişen şartlara göre yeniden kurgulanmaktadır. Malkki'ye göre "kimlik her zaman değişen ve sürece bağlı olan, biraz kendi-kendine üretilmiş olan, biraz başkaları tarafından tanınmış, bazen bir durum, bir statü, bir etiket, silah ve hatta kalkan olabilen, anılar toplamıdır”. ${ }^{44}$ Dahası, kimlikler, doğadan gelen ya da verilmiş bir şey olmadığı ve belli sosyal

40 Hobsbawm and Kertzer, "Ethnicity and Nationalism, s.4.

41 Fatos Lubonja, "Identiteti Shkiptar dhe İdentiteti Kosovar”, Korrieri, 26 Ağustos 2008.

$42 \mathrm{Bu}$ konuda en önde gelen çalışmalar için bkz. Ernest Gellner, Nations and Nationalism, Oxford, Blackwell, 1983; Benedict Anderson, Imagined Communities: Reflections on the Origin and Spread of Nationalism, Londra, Verso, 1991, ikinci basım; Eric Hobsbawm, Nations and Nationalism since 1780, Cambridge, Cambridge University Press, 1990; John Breuilly, Nationalism and the State, Manchester, Manchester University Press, 1993, ikinci basım. Özkırıml, milliyetçilik kuramcılarını "özcü” (essentialist) ve "yapılanmacı" (constructivist) olarak ikiye ayırmanın "daha yararlı olacağını" söyler. "Yapılanmacı" kavramı aslında "modernist” olarak adlandırılan ve yukarıda en önemlilerinin ismi zikredilmiş olan milliyetçilik yazarlarının ortak noktalarından birisini ortaya koyan kapsayıcı bir tanımdır. Bu ortak nokta ise, Özkırımlının ifadesiyle "modernist kategorisine dâhil edilen tüm kuramcıların değişen ekonomik, siyasi ya da toplumsal koşulların etkisiyle milleti kurgulamanın, icat, ya da hayal etmenin 'mümkün ya da zorunlu hale geldiğini iddia” etmekte olmalarıdır. Umut Özkırıml, Milliyetçilik Kuramları: Eleştirel Bir Bakış, Doğu Batı Yayınları, Şubat 2015, s.257-258.

43 Katherine Verdery, "Whither 'Nation and Nationalism', Deadalus, Cilt 122, No.3, 1993, s.39.

44 Liisa Malkki, "National Geographic: The Rooting of Peoples and the Territorialization of National Identity among Scholars and Refugees", Geoff Eley ve Ronald G. Suny (der.), Becoming National: A Reader, Oxford, Oxford University Press, 1996, s.448. 
şartlar ve çevre içerisinde anlam kazandığı için, sosyal ilişkiler kurulmadan önce var olamazlar. Diğer bir deyişle, milli kimlik, kişi ile toplum ya da birey ile devlet arasında oluşturulan ilişkilere bağlıdır. Buna ek olarak, milli kimlik, kurumların işleyişinin son derece önemli olduğu, özne ile yapı arasında karşılıklı etkileşim olarak görülebilir. Sonuç olarak, sosyal inşacı bakış açısı ile "Kosovalı" kimliğinin inşa edilmesi kuramsal olarak mümkün olabilir. Sorun bunun, bağımsızlık sonrası dönemde Kosova’da mevcut olan siyasi, ekonomik ve sosyal şartlar içerisinde nasıl gerçekleştirilebileceğidir.

Özkırıml, kimliğin yeniden üretiminin iki şekilde mümkün olabileceğini belirtmektedir: kurumsal ve kurumsal olmayan yöntemlerle. ${ }^{45}$ Kimliğin yeniden üretiminde, farklı alanlarda geliştirdiği görünür ve görünmez çeşitli mekanizmalarla en önemli rolü devletin oynadığı göz önüne alındığında bağımsızlık sonrasında oluşturulan Kosova devletinin kurumlarında da, devletin tüm vatandaşlarına "etnik ve/veya klan aidiyetlerini göz ardı ederek" eşit olarak hizmette bulunmasının hayati önem taşıdığı ortadadır. ${ }^{46}$ Devlet akrabalık ilişkileri ya da homojen bir etnik yapıya değil; tüm vatandaşlara karşılık gelmektedir. Hukukun üstünlügü, insan hakları ve demokrasi ilkeleri üzerine kurulmuş, iyi çalışan kamu kurumları ortak bir yurttaşlık kimliği ve toplumun yaratılmasında büyük rol oynamaktadır. Nitekim Kosova Meclisi de bağımsızlık bildirgesinde bunun altını dikkatle çizmektedir:

Biz [Kosova Meclisi] Kosova’yı, ayırımcılığı reddeden ve tüm vatandaşlarının hukuk önünde eşit olarak korunduğu, demokratik, seküler ve çok etnili bir cumhuriyet olarak ilan ediyoruz. Kosova'da bulunan tüm toplumların haklarını koruyacak ve geliştirecek, siyasi ve karar alma mekanizmalarına etkili bir şekilde katılımlarını sağlamak için gerekli koşulları oluşturacağız. ${ }^{47}$

Andersen’e göre "kamu kurumlarının görevi sadece vatandaşlarına en iyi şekilde nasıl hizmet edileceği konusunda demokratik olarak ortaya konmuş olan programı uygulamaktır. Çünkü kimlik, aidiyet ve ortak değerler ancak aktif olarak faaliyet gösteren kamu kurumlarıla beslenebilir”. ${ }^{48} \mathrm{Bu}$ nedenle devletin başarılı olabilmesi için aslında daha az etnik temelli milliyetçilik çağrısı yapması ve vatandaşları arasında eşitlik politikası takip etmesi gerekir. Ekonomik katma değerin yaratıldığı ve vatandaşlar arasında adil bir şekilde paylaşıldığ bir refah devletinde, tüm vatandaşlar yavaş yavaş gelir düzeylerini arttırmayı hedeflerler ve gelecekle ilgili olarak hayallerini ve isteklerini gerçekleştirmek için geleceğe umutla bakmaya başlarlar. Bu durum toplumda bir yakınlaşma hissi uyandırır ve birlikte paylaşılan yüksek bir kültür, hatta bir millet hissi yaratır. ${ }^{49}$ Nitekim, Özkırımlı’nın da belirttiği gibi millet tanımına "ortak kader" ögesini katarken Bauer ${ }^{50}$ de, kişinin devlete, millete yönelik aidiyetinde yalnız ortak geçmiş düşüncesinin değil, ortak gelecek-kader ögesinin de önemli bir yer tuttuğunu belirtmektedir. ${ }^{51}$ Smith de eşit vatandaşlık hakları ve yükümlülüklerin ve toplumun ortak ekonomik çıkarlarının ulusal kimliğin oluşturulmasına büyük katkısı olduğunun altını çizmektedir. ${ }^{52}$

Ulusal kimliğin inşa edilmesinde kurumsal olmayan yöntemlerin başında ise sadece o devlete ait olan "semboller" gelmektedir. Devletlerin siyasi sembolleri, ortak değerleri yansıtması ve o ülkede

45 Umut Özkırıml, Contemporary Debates on Nationalism: A Critical Engagement, New York, Palgrave Macmillan, 2005, s.174.

46 Aasmund Andersen,"The Kosovar Identity and Statehood”, Paper presented at the symposium 'European Identity of Kosovo' organized by Forum 2015 and the Open Society Institute, Pristina 26-28 Temmuz 2007, s.105.

47 Kosovo Declaration of Independence, http://www.assembly-kosova.org, (Erişim Tarihi: 25 Haziran 2015).

48 Andersen, “The Kosovar Identity and Statehood”, s.106.

49 Ibid., s.106-107.

50 Otto Bauer, “The Nation”, Gopal Balakrishnan (der.), Mapping the Nation, Londra, Verso, 1996, s.39-77.

51 Özkırıml, Milliyetçilik Kuramları, s.266.

52 Anthony D. Smith, National Identity, Londra, Penguin, 1991, s.75. 
yaşayan insanların paylaştığı ortak mirası göstermesi açısından son derece önemlidir. Ülkede yaşayan kişiler tarafından paylaşılan ortak değerler ya da ortak bir miras olmasa bile bu sembollerin kabul edilmesi, hissedilmesi ortak değerlerin zaman içerisinde benimsenmesini sağlayabilir. Sonntag, siyasi sembollerin en önemli fonksiyonunun geleceğe dönük olarak verdikleri vaatler olduğunu belirtmektedir: bir anlamda umudu ve bir gelecek vizyonunu ortaya koymaktadırlar. ${ }^{53}$ Kosova devleti de, 2008'de bağımsızlığını ilan ederken bayrak, milli marş ve diğer sembollerin, çok etnili yapı ve Kosova'da yaşayan farklı etnik gruplar arasında ayırım yapmama ilkesine göre seçilmesine dikkat edilmiştir. Yeni Kosova bayrağı mavi arka plan üzerine Kosova'da yaşayan en büyük altı etnik grubu (Arnavutlar, Sırplar, Türkler, Goraniler, Romanlar ve Boşnaklar) temsil eden altı beyaz yıldız ve onun altında bulunan Kosova haritasından oluşmaktadır. Kosova’da farklı diller konuşulduğu için Kosova milli marşının sözleri bulunmamaktadır.

Özkırımlı, devletlerin kullandığı bu sembollerin siyasi söylemler ve kültürel yeniden üretimler için sürekli bir arka plan sağladığını belirtmektedir. ${ }^{54}$ Özkırımlı'nın, Billig'in ${ }^{55}$ bu alanda en etkili eserlerden birisi kabul edilen çalışmasına atıfta bulunarak vurguladığı gibi, bu semboller günlük hayatın her yerinde farkında olmadan bizi etkilemekte ve o ülkede yaşayan insanların dünyadaki diğer milletler içerisindeki yerini, biz farkında bile olmadan, bize hatırlatmaktadırlar. Bu durumu ancak kendi doğal yaşam alanımızdan uzaklaştığımızda fark edebiliriz. ${ }^{56}$ Dolayısı ile Kosova'nın bağımsızlı̆ğının 2008'de ilanından bu yana geçen süre içerisinde aslında farkında olmadan, başta bayrak ve milli marş olmak üzere, yeni Kosova devletine ait sembollerin Kosova vatandaşları üzerinde yeni kimliğin oluşturulmasında etki yapmaya başlamış olduğu değerlendirilebilir.

Diğer taraftan, Hasimja, Kosova halkının büyük çoğunluğunun çok etnili ve kültürlü devlet kavramından habersiz oldukları için, seçkinlerin katkısı ve desteği olmadan Kosova kimliğinin oluşturulmasının mümkün olamayacağını belirtmektedir. ${ }^{57}$ Kosova'da yaşayan Arnavutlar ve Sırplar, iki grup arasında yaşanan büyük çatışmalardan sonra, etnik vurgusu son derece güçlü olan tek boyutlu kimliklerine bir anlamda sıkı sıkı sarılmış durumdaydılar. Fierke'ye göre "geçişken ve inşa edilmiş olmasının yanı sıra, kimliğin bir boyutu da 'çeşitlilik'tir" ${ }^{58}$ Diğer bir deyişle, yeni kimliğin üzerine inşa edilmiş olduğu eski kimlikleri göz ardı etmesi veya reddetmesi gerekmez. Kosova vatandaşları için de, yeni Kosova kimliğinin edinilmesini, etnik kimliklerin bir kenara atılması ya da terk edilmesi anlamına gelmemektedir. Lubonja "aksine ortak bir kültür geliştirerek daha zengin bir kimlik edinmek mümkün olabilir” diyerek "Kosovalı” kimliğinin, bu şekilde etnik farklılıklarına bakmaksızın, tüm Kosovalıları içine alan bir şemsiye kimlik şeklinde görülebileceğine işaret etmektedir. ${ }^{59}$

Gashi’ye göre ise Kosova kimliğinin oluşturulması iki uzun tarihsel süreç içerisinde mümkün olabilir. ${ }^{60}$ İlk aşamada, Kosova Arnavutları, Kosova Sırpları, Kosova Türkleri gibi, hem etnik hem siyasi kimliği içeren çifte kimlik söz konusuyken, ikinci aşamada Kosovalı kimliğinin oluşturulmasına geçilecektir. ${ }^{61}$ Burada en önemli sorun, etnik grupların, geçmişin milliyetçilik mitlerinden ayrılarak, yeni kimliği benimseme konusunda gösterdikleri direnç olarak ortaya çıkmaktadır.

53 Albrecht Sonntag, Political Symbols, "Citizenship and Communication", Paper Prepared for the "Communicating European Citizenship” Closing Conference, Centre for European Integration, Londra, 22 Mart 2010, s.3.

54 Özkırıml, Contemporary Debates on Nationalism, s.175.

55 Michael Billig, Banal Nationalism, Londra, Sage, 1995.

56 Özkırıml, Contemporary Debates on Nationalism, s.175.

57 Ermal Hasimja, “Inxhinjeria Identitare Kosovare”, Identiteti Evropian i Kosovës, Pristinë, 2007, s.114.

58 Karin M. Fierke, Critical Approaches to International Security, Cambridge, Polity Press, 2007, s.76.

59 Fatos Lubonja, "Identiteti Shkiptar dhe İdeniteti Kosovar".

60 Ibrahim Gashi, “A po Krijohet Identiteti Kosovar?”, Identiteti Evropian i Kosovës, Pristinë, 2007, s.119.

61 Ibid., s.122. 


\section{“Kosovalı” Kimliğinin Oluşturulma Süreci Başarılı mıdır?}

Kosova’nın bağımsızlığının Arnavutlar ile Sırplar arasında "tarihi uzlaşmayı" sağladığını söylemek mümkün değildir. Vesayet altında elde edilen bağımsızlık Kosova Arnavutlarının beklentilerini karşılamaktan uzak kalmıştır. Kosova Arnavutları, bağımsızlık bildirgesinde bir kere bile Arnavut adının geçmemesine anlam verememişlerdir. ${ }^{62}$ Benzer şekilde Arnavutluk'un tarihsel devlet sembolleri ve Arnavut halkının yüzlerce yıldır kutlamakta olduğu ulusal bayramları da yeni Kosova devleti tarafından tanınmamıştır. ${ }^{63}$ Özellikle, uzun yıllardır parçası olabilmek için çaba gösterdikleri anavatan Arnavutluk ile birleşmelerinin de yasaklanmış olması Kosova Arnavutlarının yeni kurulan Kosova devletini sorgulamalarına sebep olmuştur.

Kosova Sırpları açısından ise Kosova'nın bağımsız bir devlet olarak Sırbistan'dan ayrılması tarihi bir yenilgi olarak algılanmıştır. Hem radikal milliyetçi, hem de Avrupa Birliği yanlısı siyasi partiler bağımsızlığa karşı çıkmışlar ve bunun uluslararası hukuka aykırı olduğunu savunmuşlardır. Kosovalı Sırplar bağımsızlığın ilanına kadar Kosova’nın yönetiminde her zaman daha fazla söz sahibi olmuşlardır. Ayrıca Sırbistan'ı anavatan olarak kabul ettiklerinden geleceklerini Sırbistan'dan ayrı düşünememektedirler. Sonuç olarak, başlangıcından itibaren, Kosova Sırpları ve Kosova Arnavutları için yeni kurulan devlete karşı kendi ulusal kimliklerini unutturacak bir süreci başlatacak nitelikte bir sempati oluşmamıştır.

Bağımsızlığın ilanından sonraki süreçte Kosovalı Arnavut liderler Kosova'nın bağımsızlığı için verilen desteğin şartlı destek olduğunu bildiklerinden çok etnili kimlik oluşturulması sürecinde uluslararası denetim kurumları ile birlikte çalışmışlar ve bu süreçte yapıcı bir rol oynayamaya gayret etmişlerdir. Hatta eski Kosova Kurtuluş Ordusu liderlerinden ve Mart 2006-Ocak 2008 tarihleri arasında başbakanlık yapmış olan Agim Çeku, Kosova'da yaşayan tüm halkların haklarını tanıyan bir Kosova devletini savunmuş, buna karşılık milliyetçi Kosovalı Arnavutlar tarafından şiddetle eleştirilmiştir. ${ }^{64}$ Kosovalı liderlerin Ahtisaari projesine verdikleri desteğin gerçekten bu sürece inandıkları için mi yoksa iktidarda kalabilmek için uyguladıkları stratejinin bir parçası mı olduğu tam olarak anlaşılamamış olmakla birlikte Kosova'da yeni bir siyasi kültürün egemen olduğu görülmektedir. Genel olarak bakıldığında, Kosova'da siyasetçiler iki farklı söylem kullanmaktadırlar. Birincisi, ABD ve özellikle Avrupa Birliği’ne dönük olarak Kosova'da çok ulusluluğu ve Arnavutlar ile Sırplar arasında ortak yaşamı destekleyen "akılcı" söylem, diğeri ise sadece Kosovalı Arnavutların ulusal hedeflerine uygun "popülist milliyetçi” söylem. ${ }^{65}$ Bazı durumlarda ise her iki söylem bir arada kullanılmaktadır. Örneğin, Başbakanlığı sırasında Haşim Taçi, eski Kosova Kurtuluş Ordusu komutanlarından birisinin anısına yaptığı konuşmada, bu kişiyi "Kosova devletinin güçlendirilmesi ve vatandaşları adına yaptığı hizmetlerden dolayı övmüş ve bu sayede Kosova’nın yakın gelecekte NATO ve Avrupa Birliği’nin üyesi olmaya yaklaştığını" belirtmiştir. ${ }^{66}$

Kosova'daki sivil toplum ve orta sınıf sosyo-ekonomik nedenlerden dolayı son derece zayıf olduğu için ülkedeki siyasi seçkinlerin kamuoyu üzerindeki etkisi son derece fazladır. Halkın daha iyi eğitimli kesimi ve gazeteciler arasında yeni kimliğe daha sempati ile bakanlar bulunmaktadır. "Kosovalı" kimliğinin benimsenmesiyle ilgili olarak Sandström, Kosova Arnavutlarının, Kosova

62 Albin Kurti, "Festa qe na Bashkon”, Korrieri, 18 Şubat 2010.

63 Alma Lame, "28 Nëntori si Subkulturë", Korrieri, 30 Kasım 2009.

64 Merxhan Avdyli, “Identiteti Kosovar, Një Shpikje e Shpifur”, Identiteti Evropian i Kosovës, Pristinë, 2007, s.168.

65 Fatos Lubonja, “Të mbytesh në një fushë futbolli”, Panorama, 21 Ekim 2014, http://perpjekja.blogspot.com.tr/ (Erişim Tarihi: 25 Haziran 2015).

66 Ibid. 
sınırları içerisindeyken kendilerini "Arnavut" olarak adlandırmalarına rağmen, Arnavutluk’a gittiklerinde kendilerini "Kosovalı" olarak tanıttıklarını belirtmektedir. ${ }^{67}$ Benzer şekilde, Kosova Arnavutları Arnavutluk'tan gelen Arnavutlarla konuşurken "Kosovalı” kimliklerine vurgu yapmaktadırlar. Sandstörm'e göre, yurtdışında yaşayan Arnavutluk Arnavutları ile Kosova Arnavutları da birlikte yaşamak ya da karışmak konusunda istekli değildirler. ${ }^{68}$ Kosova’nın bağımsız olmasından sonra kültürel ilişkiler artmış olmasına rağmen bu durum değişmemiştir. Vatandaş olarak Kosovalı Arnavutların Kosova'ya aidiyetleri son derece güçlüdür.

Kosova kimliğinin oluşturulması konusundaki çabaların sonuçları şimdiye kadar son derece mütevazı olmasına rağmen özellikle yeni kuşak Kosovalılar arasında bir "Kosovalı" kimliğinin oluşmaya başladığını söylemek mümkündür. ${ }^{69}$ Bağımsız Kosova devletinde büyüyen yeni kuşak bireyler bağımsız Kosova devletini yeni sembolleri ve ideolojisi ile benimsemekte ve kendi anılarını oluşturmaktadırlar. Örneğin, judo şampiyonu Majlinda Kelmendi bu yeni kuşak Kosovalılara örnek olarak gösterilebilir. Ulusal ve uluslararası turnuvalarda genç Kosovalı atletler bağımsız Kosova bayrağını dalgalandırmaktadırlar. ${ }^{70}$

Kosova ve Arnavutluk arasındaki ilişkiler de Kosova'da ayrı bir devlet ve kimlik oluşturulması konusunda siyasi alanda ne kadar yol alındığı konusunda bilgiler vermektedir. Geleneksel olarak her iki ülkede de siyasi liderler, ekonomik refah konularında halka takdim edecek somut bir gelişme olmadığında iktidarda kalabilmek için popülist milliyetçi söylemlere başvurmaktadırlar. Bununla birlikte iki ülke arasındaki ekonomik ve ticari ilişkiler söz konusu olduğunda, Arnavutlar arasındaki milliyetçilik söylemleri bir kenara bırakılmakta, son derece rasyonel bir gündem takip edilmektedir. ${ }^{71}$ $\mathrm{Bu}$ durumda vatandaşlık etnik aidiyetten daha önemli olmaktadır. Dolayısı ile Arnavutluk ile Kosova arasındaki ilişkiler, yakın işbirliği içerisinde olan komşu ikiülke ilişkileri niteliğindedir. Zaman zaman iki taraftan da Arnavutluk ve Kosova’nın bir devlet altında birleşmesiyle "Büyük Arnavutluk" " kurulması yönünde söylemler duyulmasına rağmen bunun siyasi iradeye yansıması söz konusu değildir. Xelili, bu şekilde düşünenlerin sayısının gün geçtikçe azaldığını ve özellikle eğitim düzeyi yüksek Kosovalı Arnavutların Kosova'nın birleşik ve istikrarlı bir ülke olarak AB'ye üye olmasını tercih ettiklerini belirtmektedir. ${ }^{73}$ Kısacası Arnavutluk ile Kosova’nın yakın bir gelecekte birleşmesi konusunda güçlü bir siyasi irade görünmemektedir. Her iki ülke de geleceklerini Avrupa Birliği içerisinde görmeye başlamışlardır ve nihai hedef olan $\mathrm{AB}$ üyeliği sonucunda aralarındaki sınırın kalkmasının mümkün olacağına inanmışlardır. ${ }^{74}$

2012'de Kosova Hükümeti ile Sırbistan arasında Avrupa Birliği'nin arabuluculuğu ile görüşmelerin başlamış olması da son derece olumlu bir gelişme olmuştur. 19 Nisan 2013'de taraflar

67 Tomas Sandström, Social Identities, Citizenship, and State Building, Yayınlanmamış Yüksek Lisans Tezi, Umeå, Umeå University, Department of Political Science, 2012, s.39.

68 Ibid., s.39-41.

69 Bujar Aruqaj, "Construction of Nationalism in the Republic of Kosovo", The Politics of Deeply Divided Societies, Pristine, Fall 2013, s.4.

70 Ibid.

71 Gazeta Express, 16.10. 2014, http://www.gazetaexpress.com/lajme/serish-barriera-per-eksportin-e-miellit-neshqiperi-51826/ (Erişim Tarihi: 18 Ekim 2014).

72 Arnavutlar "Büyük Arnavutluk" sözü yerine "Etnik Arnavutluk" ya da "Doğal Arnavutluk" kavramlarını tercih etmektedirler.

73 Marisola Xhelili, "Post-Independent Kosovo: From Prescriptive to Descriptive Identities”. Independent Study Project (ISP) Collection,10.1.2010, http://www.digitalcollections.sit.edu /ispcollection/928, (Erişim Tarihi: 08 Ekim 2014), s.27.

74 European Commission, Kosovo 2013 Progress Report, Brussels, 16.10.2013, SWD (2013) 416 Final, http://ec.europa. eu/enlargement/pdf/key_documents/2013/package/ks_rapport_2013.pdf(Erişim Tarihi: 28 Haziran 2015). 
arasında varılan tarihi mutabakat Avrupa diplomasisinin zaferi olarak gösterilmektedir. Bu anlaşmaya göre Sırbistan hükümeti, 15 Temmuz 2015'den itibaren Kosova'nın kuzeyinde Sırp nüfusun yoğun olarak yaşadığı yerlerde Sırplara hizmet etmekte olan, belediye meclisleri, mahkemeler, savcılık ofisleri ve polis istasyonlarının kapatılmasını ve Kosovalı Sırp polis memurların maaşlarının ödenmesi gibi uygulamalara son vermeyi kabul etmiştir. ${ }^{75}$ Sırbistan'ın bu taleplere boyun eğmesi ancak Avrupa Birliği'nin üyelik süreci sayesinde mümkün olabilmiştir. Arnavutluk, Sırbistan ve Kosova’nın Avrupa Birliği üyeliği hedefi ile ülkeler arasındaki normalleşmenin düşünülenden daha kısa süre içerisinde gerçekleşmesi mümkün olabilir. Bu durumda Avrupa Birliği’nin yeni “Kosovalı” kimliğinin oluşturulmasında geleceğe yönelik olarak ortak bir vizyon ortaya koyarak kolaylaştırıcı rol oynayabilir.

\section{Sonuç}

Kosovalı Arnavutlar ve Kosovalı Sırplar arasındaki sorunlu etkileşimin tarihsel arka planından yola çıkılarak, bağımsızlık sonrasındaki süreçte ortak bir "Kosovalı" kimliğinin oluşturulmasının mümkün olup olamayacağını inceleyen bu makalede, ulusların, oluşumunda milliyetçiliğin büyük rol oynadığı sosyal olarak inşa edilmiş yapılar olduğunu savunan sosyal inşacı kuram kullanılmıştır. Yine sosyal inşacı yaklaşıma göre ulusal kimliğin, durağan ve değişmez değil, ekonomik, siyasi ve sosyal süreçler ile şekillendirilmiş, geçişken bir niteliğe sahip olduğu kabul edildiğinde bağımsızlık süreci sonrasında kurulmuş olan yeni Kosova devletinin yeni bir "Kosovalı" kimliği oluşturmasının kuramsal olarak mümkün olduğu iddia edilmiştir. Bu çerçevede yapılan analizde Kosova’nın, Şubat 2008'de ilan edilen bağımsızlık bildirgesinde de belirtildiği üzere çok etnili ve çok kültürlü "Kosovalı" kimliğinin kaynağını oluşturan Kosova devletinin anayasal temelleri incelenmiştir. Ahtisaari Planı́nın temel prensipleri olan hukukun üstünlügü ve insan haklarına saygı gibi faktörlerin doğrudan yansitıldığı Kosova Anayasasında belirtilen prensiplerin etnik köken, din ve dil farkı gözetilmeden tüm Kosova halkına yönelik olarak uygulanmasının bağımsızlık sonrasında Kosova toplumunun oluşturulması açısından büyük önem taşıdığı sonucuna varılmıştır.

Yine sosyal inşacı kuram temel alınarak ulusal kimliklerin doğadan gelen ve önceden verilmiş olmadığı ve belli sosyal şartlar ve çevre içerisinde anlam kazandığı varsayımından hareket edilerek milli kimliğin oluşturulmasının birey ile devlet arasında oluşturulan ilişkilere bağlı olduğu önermesi yapılmıştır. $\mathrm{Bu}$ önerme ile yeni kurulan Kosova devletinin Kosovalı kimliğinin oluşturulmasında oynayacağı rol üzerinde durularak, bu konuda örnekler verilmeye çalışılmıştır. Bu çerçevede hukukun üstünlüğü, insan hakları ve demokrasi ilkeleri üzerine kurulmuş "etnik ve/veya klan aidiyetlerini göz ardı ederek" vatandaşlarına eşit hizmette bulunan ve iyi çalışan kamu kurumlarının ortak bir yurttaşlık kimliği yaratılmasında büyük rol oynadığı vurgulanmıştır. Buna ekonomik olarak daha müreffeh bir geleceğin yaratılması hedefi eklendiğinde ve yeni Kosova devletinin yurttaşları bu amaç etrafında ortak bir kader belirlediklerinde yeni kimliklerini benimsemek konusunda daha istekli olacaklardır.

Makalede ayrıca ulusal kimliğin inşa edilmesinde son derece etkili, sadece o devlete ait olan siyasi sembollerin ortak değerleri yansıtması açısından son derece önemli olduğu vurgulanmaktadır. 2008'de ilan edilen bağımsızlık sırasında Kosova devletinin bayrak, milli marş ve diğer sembolleri, başta Kosovalı Arnavutlar ve Sırplar olmak üzere, Kosova'da yaşayan farklı etnik gruplar arasında ayırım yapmama ilkesine göre seçilmiştir. Örneğin Kosova'da farklı diller konuşulduğu için Kosova milli marşının sözleri bulunmamaktadır. 
Kosovalı kimliğinin oluşturulma sürecinin başarılı olup olmadığı konusuna gelindiğinde, Kosova’nın bağımsızlığının sekizinci yıldönümünde, Kosovalı Arnavutlar ve Sırplar arasında tarihi bir uzlaşmanın gerçekleştiğinden söz etmek mümkün değildir. Kosovalı Arnavutlar ve Sırplar yeni kurulan devletin kuruluşunda aradıklarını bulamamışlar ve tepki göstermişlerdir. Bununla birlikte, bağımsızlığın ilanından sonraki süreçte Kosovalı Arnavut liderler yeni bir Kosovalı kimliği oluşturulması yönünde uluslararası denetim kurumları ile birlikte çalışmışlar ve bu süreçte attıkları her adıma dikkat ederek yapıcı bir rol oynamaya çalışmışlardır. Bu noktada, Kosova'daki sivil toplum ve orta sinıfın sosyo-ekonomik ve tarihi sebeplerden dolayı son derece zayıf olduğu tespitinden yola çıkılarak siyasi seçkinlerin kamuoyu üzerindeki etkisinin bir hayli fazla olduğu değerlendirilmesi yapılmaktadır. Aradan geçen sekiz yıl içerisinde Kosova'da yeni bir siyasi ve ekonomik kültürün egemen olmaya başladığı görülmektedir.

Sonuç olarak, ulusal kimliğin yeniden üretilmesi sürecinde ele alınan Kosova örneğinin incelenmesi sonucunda sosyal inşacı kuramsal yaklaşımın öne sürdüğü gibi yeni bir "Kosovalı kimliğinin oluşturulmasının” pratikte mümkün olabileceğinin ipuçları ortaya çıkmaktadır. Nitekim "Kosovalı" kimliğinin oluşturulması konusundaki çabaların sonuçları son derece mütevazı olmasına ve bağımsızlığın üzerinden sadece sekiz yıl gibi kısa bir süre geçmiş olmasına rağmen, özellikle bağımsız Kosova devletinde büyüyen yeni kuşak Kosovalı bireylerin Kosova devletini yeni sembolleri ve ideolojisi ile benimsedikleri ve günlük yaşamları içerisinde farkında olmadan bu yeni kimliği yansıtmaya başladıkları gözlenmiştir. 


\section{Kaynakça}

Andersen, Aasmund.“The Kosovar Identity and Statehood”, Identiteti Evropian i Kosovës, Pristinë, 2007, s.105-108.

Anderson, Benedict. Imagined Communities: Reflections on the Origin and Spread of Nationalism, Londra, Verso, 1991, ikinci basım.

Ahtisaari, Martti. Report of the Special Envoy of the Secretary-General on Kosovo's Future Status, 15 Mart 2007, http://www.unosek.org, (Erişim Tarihi: 1 Temmuz 2015).

Annan, Kofi. "Letter dated 7 October 2005 from the Secretary-General addressed to the President of the Security Council”, 7 Ekim 2005, http://www.unosek.org, (Erişim Tarihi: 30 Haziran 2015).

Aruqaj, Bujar. "Construction of Nationalism in the Republic of Kosovo", The Politics of Deeply Divided Societies, Pristine, Fall 2013.

Aruqaj, Bujar. "Study Case: National Identity Construction in the Republic of Kosovo”, Josef Korbel School of International Studies- University of Denver, Comparative State-Building Studies, Bahar 2014.

Avdyli, Merxhan. “Identiteti Kosovar, Një Shpikje e Shpifur”, Identiteti Evropian i Kosovës, Pristinë, 2007, s.167-170.

Bauer, Otto. “The Nation”, Gopal Balakrishnan (der.), Mapping the Nation, London, Verso, 1996, s.39-77.

Bellamy, Alexander J. “The Human Wrongs in Kosovo”, Ken Booth (der.), Kosovo Tragedy, The Human Rights Dimension, Londra, Frank Cass, 2002, s.105-126.

Billig, Michael. Banal Nationalism, London, Sage, 1995.

Breuilly, John. Nationalism and the State, Manchester, Manchester University Press, 1993, ikinci basım.

Christopher Cviic, Remaking the Balkans, London, The Royal Institute of International Affairs, 1991.

Daskalovski, Zhidas. "Claims to Kosovo: Nationalism and Self-Determination”, Florian Bieber ve Zhidas Daskalovski (der.), Understanding the War in Kosovo, London, Frank Cass, 2005, s.11-27.

Durch, William J. "Keeping the Peace: Politics and Lessons of the 1990s", William J. Durch (der.), UN Peacekeeping, American Policy and the Uncivil Wars of 1990s, New York, St. Martin's Press, 1996, s.1-34.

European Commission, Kosovo 2013 Progress Report, Brussels, 16.10.2013, SWD (2013) 416 Final, http:// ec.europa.eu/enlargement/pdf/key_documents/2013/package/ks_rapport_2013.pdf (Erişim Tarihi: 28 Haziran 2015).

Fierke, Karin M. Critical Approaches to International Security, Cambridge, Polity Press, 2007.

Cornelius Friesendorf, “Kosovo's Controversial Independence”, CSS Analysis in Security Policy, Cilt 3, No.29, Mart 2008, http://www.css.ethz.ch/publications/pdfs/CSS-Analyses-29.pdf, (Erişim Tarihi: 1 Temmuz 2015).

Gashi, Ibrahim. “A po Krijohet Identiteti Kosovar?”, Identiteti Evropian i Kosovës, Pristinë, 2007, s.119-125.

Gazeta Express, 16.10. 2014, http://www.gazetaexpress.com/lajme/serish-barriera-per-eksportin-e-miellit-neshqiperi-51826/ (Erişim:18 Ekim 2014).

Gellner, Ernest. Nations and Nationalism, Oxford, Blackwell, 1983.

Gow, James. “Deconstructing Yugoslavia”, Survival, Cilt 33, No.4, 1991, s.291-311.

Guzina, Dejan. "Kosovo or Kosova-Could It Be Both? The Case of Interlocking Serbian and Albanian Nationalisms”, Florian Bieber ve Zhidas Daskalovski (der.), Understanding the War in Kosovo, London, Frank Cass, 2005, s.29-49.

Hasimja, Ermal. “Inxhinjeria Identitare Kosovare”, Identiteti Evropian i Kosovës, Pristinë, 2007, s.113-115.

Hobsbawm, Eric. Nations and Nationalism since 1780, Cambridge, Cambridge University Press, 1990.

Hobsbawm, Eric ve David J. Kertzer, Ethnicity and Nationalism in Europe Today, Anthropology Today, Cilt 8, No.1, Şubat 1992, s.3-8.

Hopkinson, Bryan. “The International Administration of Kosovo since 1999”, Brad K. Blitz (der.), War and Change in the Balkans: Nationalism, Conflict and Cooperation, Cambridge, Cambridge University Press, 2006, s.169-176. 
Judah, Tim. Kosovo: War and Revenge, New Haven, Yale University Press, 2002.

Kim, Julie ve Steven Woehrel. "Kosovo and U.S. Policy: Background to Independence", CRS Report for Congress, 20 Haziran 2008.

Kosovo Declaration of Independence, http://www.assembly-kosova.org, (Erişim Tarihi: 25 Haziran 2015).

Guiding Principles of the Contact Group for a Settlement of the Status of Kosovo, http://www.unosek.org, (Erişim Tarihi: 30 Haziran 2015).

Lame, Alma. "28 Nëntori si Subkulturë”, Korrieri, 30 Kasım 2009.

Lubonja, Fatos. “Identiteti Shkiptar dhe İdeniteti Kosovar”, Korrieri, 26 Ağustos 2008.

Lubonja, Fatos. “Të mbytesh në një fushë futbolli”, Panorama, 21 Ekim 2014, http://perpjekja.blogspot.com.tr/ (Erişim Tarihi: 25 Haziran 2015).

Magaš, Branka. The Destruction of Yugoslavia: Tracking the Break-up, 1980-1992, London, Verso, 1993.

Malcolm, Noel. Kosovo: A Short History, London, Macmillan, 1998.

Malkki, Liisa. "National Geographic: The Rooting of Peoples and the Territorialization of National Identity among Scholars and Refugees", Geoff Eley ve Ronald G. Suny (der.), Becoming National: A Reader, Oxford, Oxford University Press, 1996, s.434-455.

Misha, Piro. "Invention of a Nationalism: Myth and Amnesia", Stephanie Schwandner-Sievers ve Bernd J. Fischer (der.), Albanian Identities: Myth and History, Bloomington: Indiana University Press, 2002, s.33-48.

Osmançavuşoğlu, Emel G. The Wars of Yugoslav Dissolution and Britain's Role in Shaping Western Policy: 19911995, Ankara, Dışişleri Bakanlığı Stratejik Araştırmalar Merkezi Yayınları, 2000.

Özkurıml, Umut. Contemporary Debates on Nationalism: A Critical Engagement, New York, Palgrave Macmillan, 2005.

Özkırımlı, Umut. Milliyetçilik Kuramları: Eleştirel Bir Bakış, Doğu Batı Yayınları, Ankara, Şubat 2015.

Perritt, Henry H. Kosovo: The Road to Independence, Cambridge, Cambridge University Press, 2010.

Poulton, Hugh. The Balkans: Minorities and States in Conflict, London, Minority Rights Publications, 1993.

Pula, Besnik. "The UN in Kosova: Administering Democratization?", Florian Bieber ve Zhidas Daskalovski (der.), Understanding the War in Kosovo, London, Frank Cass, 2005, s.195-212.

Schmit, Oliver Jens. Skenderbeu, Ardian Klosi (Çev.), Tirane, K \& B, 2009.

Silber, Laura ve Alan Little. The Death of Yugoslavia, Harmondsworth, Penguin, 1996.

Thaci, Hashim. Declaration of Independence Speech, 17 Şubat 2008, www.assemblykosova.org, (Erişim Tarihi: 25 Haziran 2015).

Sandström, Tomas. Social Identities, Citizenship, and State Building, Yayınlanmamış Yüksek Lisans Tezi, Umeå, Umeå University, Department of Political Science, 2012.

Shtylla, Zamir. "The Deportation of Albanians in Yugoslavia After the Second World War”, K. Prifti et. al. (der.) The Truth on Kosova, Tirana, Encylopedia Publishing House, 1993, s.237-253.

Smith, Anthony D. National Identity, London, Penguin, 1991.

Sonntag, Albrecht. "Political Symbols, Citizenship and Communication", Paper Prepared for the "Communicating European Citizenship" Closing Conference, Centre for European Integration, Londra, 22 Mart 2010.

Statement by the Contact Group on the Future of Kosovo,31 Ocak 2006, http://www.unosek.org, (Erişim Tarihi: 30 Haziran 2015).

Xhelili, Marisola. "Post-Independent Kosovo: From Prescriptive to Descriptive Identities". Independent Study Project (ISP) Collection,10.1.2010, http://www.digitalcollections.sit.edu /ispcollection/928, (Erişim Tarihi: 08 Ekim 2014).

Verdery, Katherine. "Whither 'Nation and Nationalism', Deadalus, Cilt 122, No.3, 1993, s.37-46. 